\title{
Dieback disease of Dalbergia sissoo trees of some major areas of district Swabi
}

\author{
Gulnaz Parveen ${ }^{1 *}$, Sidra Zain ${ }^{1}$, Zubia Rahim ${ }^{1}$ and Ghulam Rasul ${ }^{2}$ \\ 1. Department of Botany, Women University, Swabi, Swabi-Pakistan \\ 2. Planning and Development Division Pakistan Agricultural Research Council-Pakistan \\ *Corresponding author's email: gulnaz.malik3@gmail.com \\ Citation \\ Gulnaz Parveen, Sidra Zain, Zubia Rahim and Ghulam Rasul. Dieback disease of Dalbergia sissoo trees of \\ some major areas of district Swabi. Pure and Applied Biology. Vol. 8, Issue 2, pp1157-1162. \\ http://dx.doi.org/10.19045/bspab.2019.80057
}

\begin{tabular}{|c|c|c|c|}
\hline Received: 25/01/2019 & Revised: $27 / 03 / 2019$ & Accepted: 02/04/2019 & Online First: $10 / 04 / 2019$ \\
\hline
\end{tabular}

\section{Abstract}

A survey of various areas of District Swabi including Saleem Khan, Nogram and Gulo Dheri was carried out in different seasons to find out the disease of Dalbergia sissoo. Different parts of the plant like roots, barks and leaves were collected and analyzed for disease causative agents and data was recorded. Maximum infection percentage of Fusarium sp., including Fusarium solani (55.55\%), Fusarium oxysporum (55.55\%) and Rhizoctonia solani (66.66\%) was reported in roots of Dalbergia tree located in the area of Saleem Khan, Swabi. While the bark and leaves of the Delbergia trees were found infected with Macrophomina phaseolina, showing maximum infection percentage $(77.77 \%)$ in the area of Saleem Khan Swabi. Similarly the infection percentage of Macrophomina phaseolina was observed maximum in roots, barks and leaves i.e. $88.88 \%, 55.55 \%$ and $77.77 \%$ respectively in the region of Nogram swabi. The site examined like Gulo Dheri shows that the infection percentage of Macrophomina phaseolina was highest in roots $(88.88 \%)$ and leaves $(100 \%)$ while the infection percentage of Rhizoctonia solani was highest in bark (77.77\%).

Keywords: Fusarium sp; Infection; Pathogens; Sheesham; Survey

\section{Introduction}

Dalbergia sissoo is a very important and multiuse tree of South Asia [1]. It is very important medicinally $[2,3]$, and widely used by people traditionally to cure many diseases. The plant also shows antipyretic and analgesic properties [4]. The timber of D. sissoo is hard and is used in making furniture [5]. The ethanoic extract of $D$. sissoo has powerful anti-inflammatory effect [6].The leaves, bark, and wood of Dalbergia tree are used as expectorant, anthelmintic, antipyretic and abortifacient [7]. People of India and Nepal used leaves extract to cure dysentery, sore throats, gonorrhea, heart problems and syphilis [8]. The leaves extract of D. sissoo has antioxidant activity [9]. D. sissoo has property of analgesic, anti-inflammatory and antipyretic [10]. D. sissoo tree also has the potential of nitrogen fixing that's why it is considered as a very important tree [11, 12].

During the survey of a few areas of Punjab it is found that about $80 \%$ of Dalbergia trees along the canal bank are infected from the wilting and dieback disease and about $20-40 \%$ of the trees are infected along the highways and roadsides while the trees growing in the fields are less affected by the wilt and dieback diseases [13]. The maximum frequency of disease (i.e. 53\%) was recorded in trees planted on irrigated lands while minimum frequency (i.e. 8.3\%) was recorded on farmlands. The common pathogens were $F$. solani, Botryodiplodia theobromae, Phytophthora cinnamomi and $F$. oxysporum [14]. Dieback disease of $D$. 
sissoo is considered to be due to the pathogenic bacteria i.e. Pseudomonas [15]. The pathogenic bacteria, Pseudomonas and Bacillus play important role in causing Dieback disease of Dalbergia [16].

From last few years Dalbergia trees are suffering from wilting and dieback diseases $[7,8,17]$, in Asia it is considered as the most bethink problem especially in Pakistan. $F$. solani was the causative agent of the dieback disease [19]. The dieback and wilt disease of $D$. sissoo is considered to be due to the pathogenic fungi, B.theobromae, F. solani, P. cinnamomi, F. oxysporum and Ganoderma lucidum [17, 20]. $F$. solani and $F$. oxysporum cause wilting of Dalbergia either alone or together [21]. Four species of Aspergillus i.e. A. flavus, A. fumigatus, A. japonicus and A. teerius cause failure of seeds to germinate [22]. Ceratocystis is the major pathogen of D. sissoo trees [23].

The distribution of different fungi vary on Dalbergia tree i.e. $F$. oxysporum is distributed frequently in stem and $R$. solani is distributed in leaves while $B$. theobromae is widely distributed in whole parts of the plant like roots, stem, twigs and bark. Thus $B$. theobromae is considered as the most frequent causative agent of dieback disease [24]. The present resistant species of Dalbergia, that show resistant to dieback are actually the progeny of susceptible variety that have undergone some changes in their genotype [25].

The oil extracted from Putranjiva roxburghii has antifungal property and stop the activity of $F$. solani and $F$. oxysporum [21]. Use of Pseudomonas. koreensis AS15 can raise disease resistant of D. sissoo [26]. Scientists worked on Dieback disease of Dalbergia sissoo and identified the different pathogens to cause the disease. While the fluctuations in data in the previous work was observed so that the aim of the present study is to identify the causative agents and actual reason of Dieback disease in Dalbergia sissoo.

\section{Methods and materials}

\section{Survey and collection of diseased samples}

A survey of different areas of Swabi district was carried out in order to collect the samples of Dalbergia sissoo trees showing symptoms of dieback disease (Figure.1). Samples were collected from road sides, along canals, water channels and also on agriculture lands. The diseased samples, including bark, leaves and roots, were kept separately in zip lock sterilized polythene bags, labeled and then brought to the laboratory for the isolation of associated pathogens [27].

The samples were placed in refrigerator at $4^{\circ} \mathrm{C}$ and isolation of associated pathogens was done within 24 hours.

\section{Isolation of associated pathogens from infected roots, leaves and bark}

Roots, leaves and bark were washed in the running tap water, cut into $1 \mathrm{~cm}$ small pieces and treated by $1 \% \mathrm{Ca}(\mathrm{OCl})_{2}$ solution. $1 \mathrm{~cm}$ small parts of tap root, leaves and bark were then transferred on potato dextrose agar (PDA) having streptomycin $(0.2 \mathrm{~g} / \mathrm{L}$ and penicillin (100000 units/L) plates and incubated at $28^{\circ} \mathrm{C}$ for five days.

\section{Identification of pathogens}

After incubation period the growth of fungi was observed on roots, barks and leaves pieces, isolated and identified by keys prescribed by $[24,28,29]$. Infection and colonization percentage of different pathogens were calculated by following formula.

Infection $\%=$ No of plants infected by pathogen / Total No. of plants $\times 100$

Colonization $\%=$ No of root pieces colonized by pathogen / Total No. of root pieces of all Plants $\times 100$ 


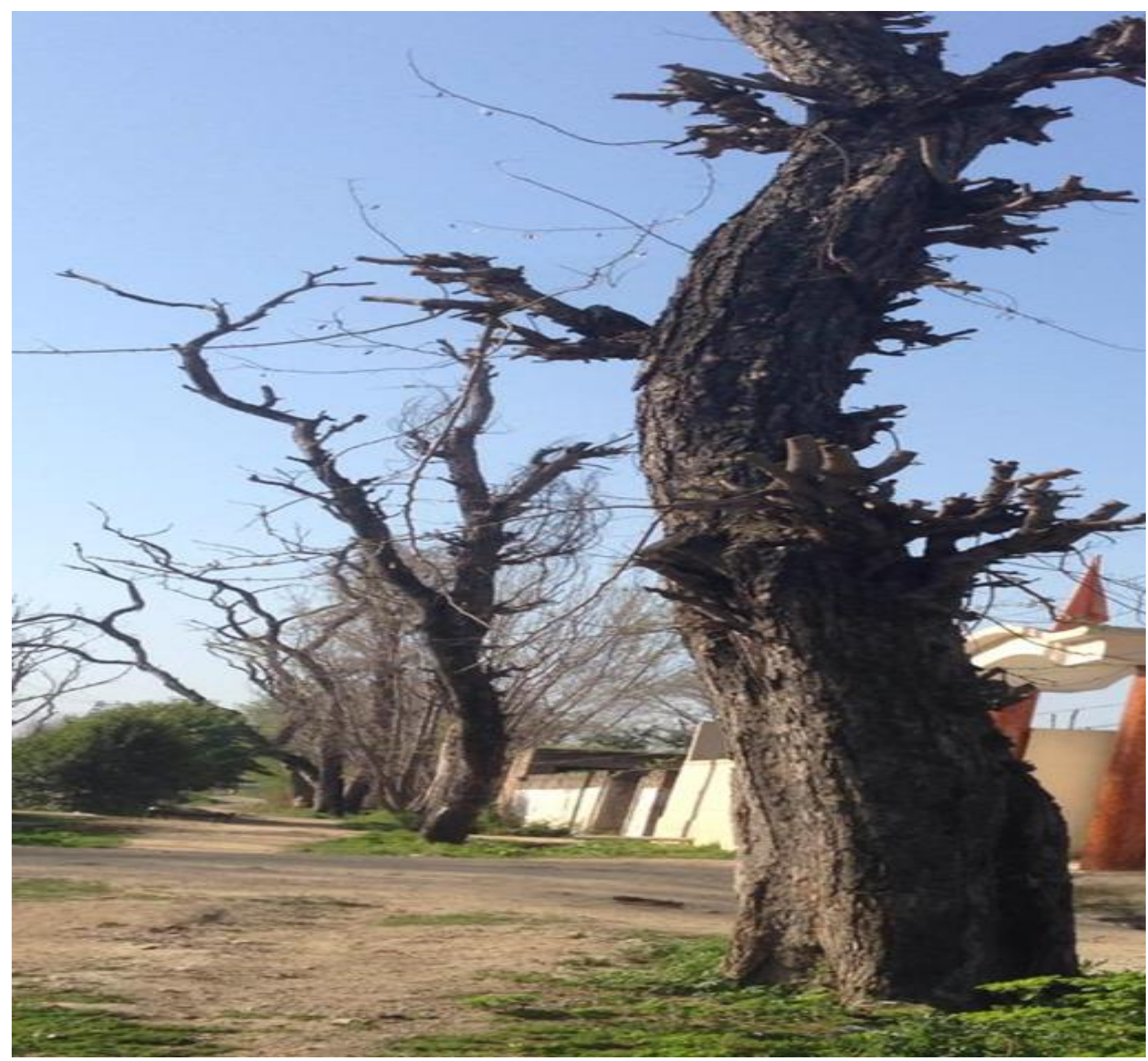

Figure 1. Trees of Delbergia sissoo showing symptoms in the area of Nogram located in District Swabi

\section{Results}

Among all the pathogens, the percentage infection of $M$. phaseolina was highest i.e. (88.88) in the roots of $D$. sissoo located in the area of Nogram and Gulo Dheri while in Saleem Khan, $R$. solani was found in highest percentage (66.66). M. phaseolina (44.44) in Saleem Khan while R. solani was (77.77) both in Nogram and Gulo Dheri. Maximum percentage infection of $F$. solani was recorded at the site of Nogram compared to other visited areas i.e. 77.77, 55.55 and 55.55 in Nogram, Saleem Khan and Gulo Dheri respectively. Similarly the sites of Saleem Khan, Nogram and Gulo Dheri the percentage infection of $F$. oxysporum was 55.55, 22.22and 44.44 respectively. Percentage infection of $F$. moniliforme (11.11) and Botrytis sp (11.11) was only found in root isolated from the site of Saleem Khan and was not observed in Nogram and Gulo Dheri (Figure 2). While highest colonization percentage of M.phaseolina, F.solani and R.solani were $35.5,26.66$ and 28.85 respectively recorded in root in the area of Saleem khan (Figure.3). The percentage infection of $M$. phaseolina (77.77) was highest in the bark of D. sissoo collected from Saleem Khan as compared to Nogram (55.55) and Gulo Dheri (66.66). While percentage infection of F. solani (55.55), F. oxysporum (55.55) and $R$. solani (77.77) was highest in the bark of Gulo Dheri compared to Nogram and Saleem khan (Figure 4). Similarly the highest colonization percentage of 
M.phaseolina, was 46.66 in bark of the plant in the area of Nogram while F.solani (22.22) in Saleem khan and R.solani (35.55) in the area of Gulo Dheri were recorded. (Figure.5).

The percentage infection of $M$. phaseolina (100) was higher in leaves of D. sissoo collected from Gulo Dheri, compare to the tree located in the area of Saleem Khan and Nogram (77.77) and (77.77) respectively. While percentage infection of $F$. oxysporum (66.66) and $F$. moniliforme (44.44) was higher in leaves of Nogram than that of Gulo Dheri $F$. oxysporum (11.11) recorded while the site visited Saleem Khan showed percentage infection of $F$. oxysporum (33.33) only. The percentage infection of $F$. solani (44.44) was same in leaves of $D$. sissoo tree collected from Nogram and Gulo Dheri and (22.22) in the sits of Saleem Khan. Similarly the percent infection of $R$. solani was same and higher in the area of Saleem Khan and Nogram (66.66)) compared to the site of Gulo Dheri that was (55.55) (Figure 6). F.solani, M.phaseolina, R.solani and Botrytis spp percent colonization were recorded highest, 28.88, 62.22, 35.55 and 37.77 respectively in the area of Saleem khan (Figure 7).

\section{Discussion}

The pathogenic fungi like $R$. solani, Curvularia lunata, $F$. equiseti, $F$. moniliforme, $F$. oxysporum, $F$. solani, $F$. semitectum, Aspergillus niger, Alternaria alternate and penicillium are the major reason of Shisham decay in Pakistan [30]. Several pathogenic fungi such as Ganoderma lucidum, F. solani, $R$. solani, $P$. cinnamomi, $C$. lunata, A. niger, $A$. flavus, Colletotrichum gloeosporioides and A. alternate were isolated from the diseased parts of D. sissoo trees [31]. In present study the pathogens which were isolated from the roots, barks and leaves of Dalbergia sissoo, collected from different areas of District Swabi i.e. Saleem Khan, Nogram and Gulo Dheri, were $M$. phaseolina, $F$. solani, $F$. oxysporum, $F$. moniliforme, $R$. solani and Botrytis sp. While the major pathogen that was present highly in percentage were M.phaseolina and F.solani which caused decline of Dalbergia sissoo trees. Similar research was done by $[17,24,32]$ that the main cause of dieback disease of Dalbergia sissoo is $F$. solani. The pathogenic fungi, $F$. solani is mostly limited to roots of Shisham plants $[33,34]$. The highest number of pathogens was recorded in the root samples than in twigs and bark samples [14]. F. solani was mostly found in roots and stem while Colletotrichum sp. was found only in stem [35]. In present study it was observed that the infection $\%$ of $F$. solani was highest in roots as compared to bark and leaves. Similarly $F$. solani inoculated in Shisham plants created maximum disease incidence, and produced prominent symptoms of the disease with internal browning of roots and stem. However, $C$. lunata and $R$. solani completely unsuccessful or affected very rare infection on test plants [36].

The incidence of disease is associated with biotype and zonal environmental factors. However, high genetic variability was found among the pathogenic isolates of $F$. solani, and it is the major cause of epidemic and determination of shisham dieback [37]. 



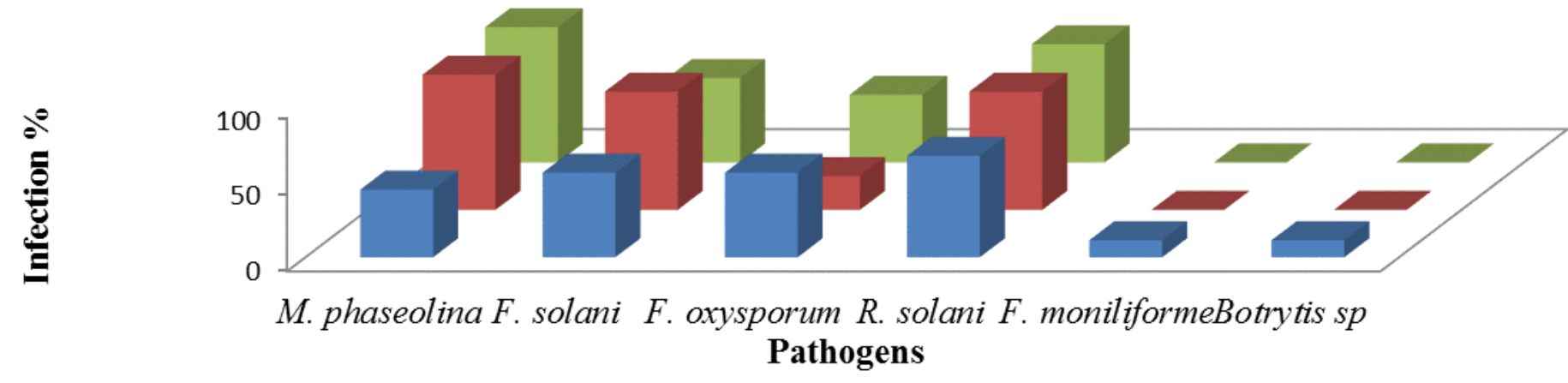

- Saleem Khan

- Nogram

Gulo Dheri

Figure 2. Infection \% of fungal pathogens isolated from the roots of Dalbergia Sissoo

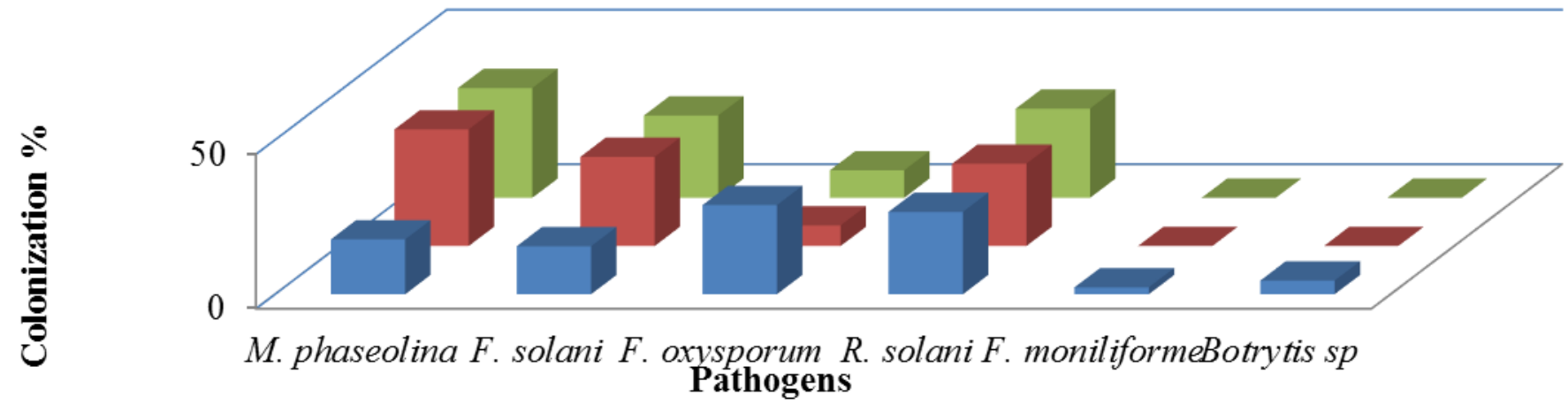

- Saleem Khan

- Nogram

Gulo Dheri

Figure 3. Colonization \% of fungal pathogens isolated from the roots of Dalbergia Sissoo 


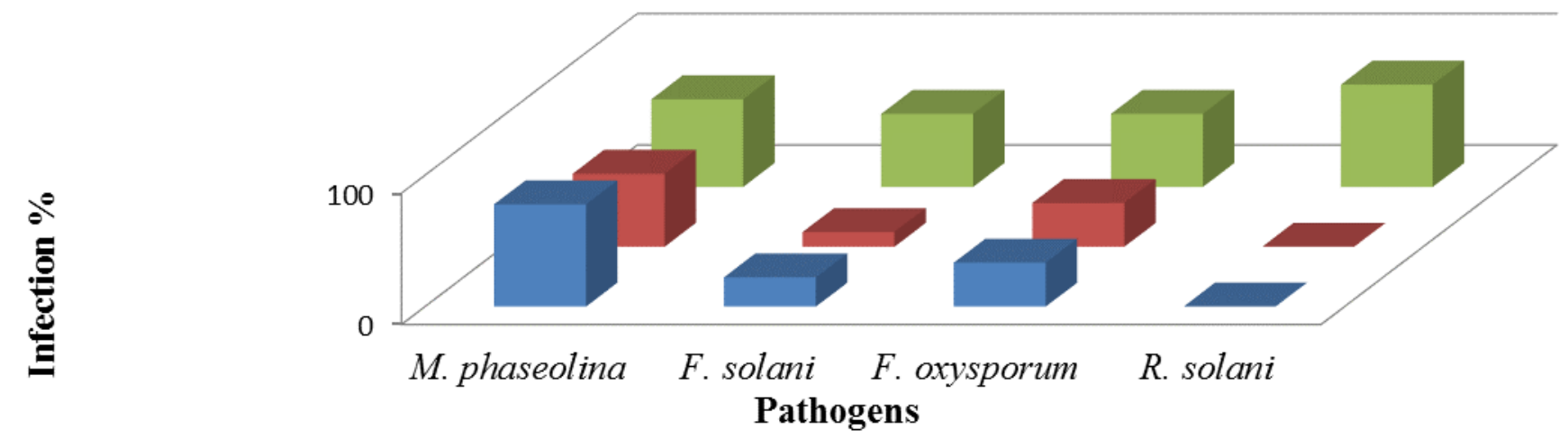

- Saleem Khan

- Nogram

Gulo Dheri

Figure 4. Infection \% of fungal pathogens isolated from the bark of Dalbergia Sisso

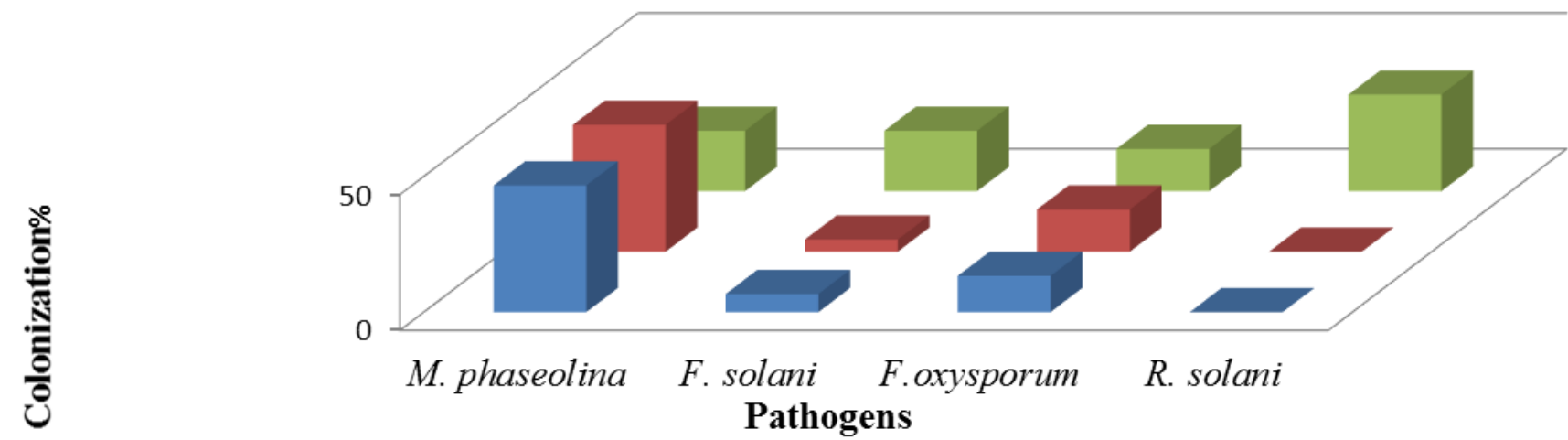

- Saleem Khan

- Nogram

Gulo Dheri

Figure 5. Colonization \% of fungal pathogens isolated from the bark of Dalbergia Sisso 


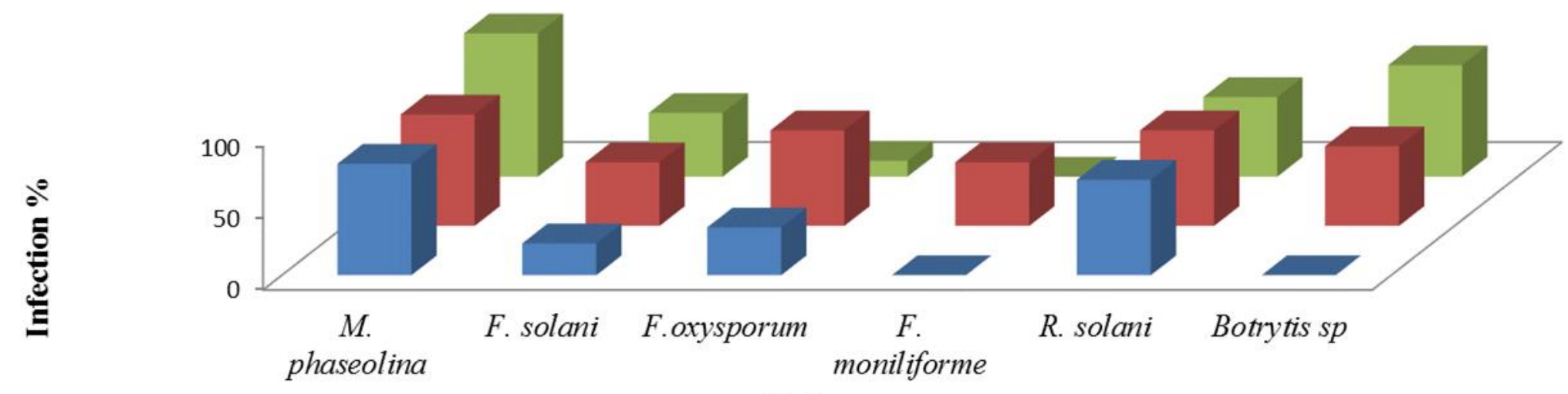

n Saleem Khan

- Nogram

Gulo Dheri

Pathogens

Figure 6. Infection \% of fungal pathogens isolated from the leaves of Dalbergia sissoTree

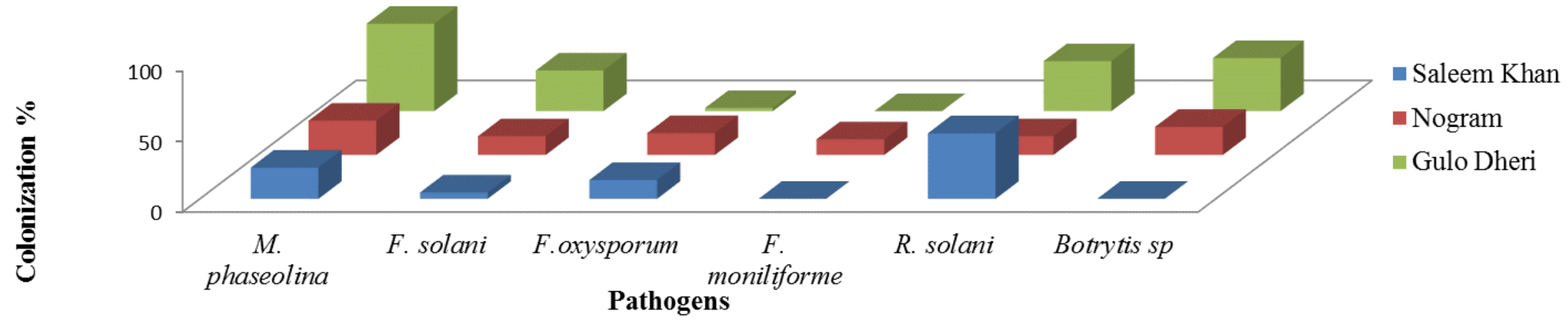

Figure 7. Colonization \% of fungal pathogens isolated from leaves of Dalbergia sisso 


\section{Conclusion}

It is concluded that the highest infection of $F$. solani was in roots as compared to bark and leaves. While incidence of M.phaseolina and R.solani were observed in all selected areas of district Swabi and the combination of these pathogens increased the severity of dieback disease of Delbergia sissoo.

\section{Authors' contributions}

Conceived and designed the experiments: $G$ Parveen, Performed the experiments: $S$ Zain, Analyzed the data: G Parveen \& G Rasul, Contributed materials/ analysis/ tools: G Parveen, Wrote the paper: $G$ Parveen \& Z Rahim.

\section{References}

1. Singh B, Yadav R \& Bhatt BP (2011). Effect of mother tree ages, different rooting mediums, light conditions and auxin treatments on rooting behavior of Dalbergia sissoo branch cuttings. J For Res 22: 53-57.

2. Pooja P, Sharma KC, Samanta \& Garg V (2010). Evaluation of nitric oxide and hydrogen peroxide scavenging activity Dalbergia sissoo roots. Pharmacophore 1: 77-81.

3. Asif M, \& Kumar A (2011). Phytochemical investigation and evaluation of antinociceptive activity of ethanolic extract of Dalbergia sissoo (Roxb.) bark. J Nat Sci Bio Med 2: 76-79.

4. Bhattcharya M, Singh A \& Ramrakhyani C (2014) Dalbergia sissoo - An important medicinal plant. $J$ of Medicinal Plant Stu 2(2): $76-82$.

5. Hossain SMY \& Martin AR (2013). Merchantable timber production in Dalbergia sissoo plantations across Bangladesh: regional patterns, management practices and edaphic factors. J Trop For Sci 25: 299-309.

6. Asif M \& Kumar A (2009). Antiinflammatory activity of ethanolic extract of Dalbergia sissoo (Roxb.) bark. Malaysian J of Pharma Sci 7: 39-50.

7. Shah MH, Mukhtar I \& Khan SN (2010). Medicinal importance and association of pathological constraints with Dalbergia sissoo. Pak J Phytopathol 22(2): 135-138.

8. Al-Quran S 2008. Taxonomical and Pharmacological Survey of Therapeutic
Plants in Jordan. J of Nat Products 1: 1026.

9. Yadav H, Yadav M, Jain S, Bhardwaj A, Singh V, Parkash O \& Marotta F (2008). Antimicrobial property of a herbal preparation containing Dalbergia sissoo and Datura tramonium with cow urine against pathogenic bacteria. Inter $J$ Immunopathol Pharmacol 21(4): 1013-20

10. Shrestha S.P, Amano Y, Narukawa Y, \& Takeda T (2008). Nitric oxide production inhibitory activity of flavonoids contained in trunk exudates of Dalbergia sissoo. J of Nat Products (71): 98-10.

11. Kausar P, Chohan S \& Parveen R (2009). Physiological studies on Lasiodiplodia theobromae and Fusarium solani, the cause of shisham decline. Mycopath 7(1): 35-38.

12. Lal HS \& Singh S (2012). Ethnomedicinal uses of Dalbergia sissoo Roxb in Jharkhand. Int. J. Ayur \& Herb Med 2(1): 198-201.

13. Bajwa R \& Javaid A (2007). Integrated disease management to control Shisham (Dalbergia sissoo Roxb.) decline in Pakistan. Pak J Bot 39: 2651-2656.

14. Rehman A, Sahi ST, Khan MA, Mehboob S (2012). Fungi Associated With Bark, Twigs and Roots of Declined Shisham (Dalbergia sissoo Roxb.) Trees in Punjab, Pakistan. Pak J Phytopathol 24(2):152158.

15. Valdez N, Karlovsky P, Dobrindt L, Imdadul Hoque M, Sarker RH, Tantau H, \& Muhlbach HP (2013). Role of Bacteria in Dieback Disease of Dalbergia sissoo Roxb. Bangladesh J Bot 42(1): 1-16.

16. Aktar L, Shamimul Alam SK, Imdadul HM, Sarker RH \& Saha ML (2016). Bacteria Associated with the Die-back Disease of sissoo Trees (Dalbergia sissoo Roxb.) in Bangladesh. Imperial $J$ of Interdisciplinary Res (IJIR) 2(12): 13241329.

17. Ahmad I, Khan RA \& Siddiqui MT (2013). Incidence of dieback disease following fungal inoculations of sexually and asexually propagated Shisham (Dalbergia sissoo). For Path 43(1): 77-82.

18. Ahmad I, Atiq M, Gul S, Hannan A, Siddiqui MT, Nawaz MF, Asif M \& Ahmed S. (2016). Dieback Disease Predictive Model for Sexually and 
Asexually Propagated Dalbergia Sissoo (Shisham). Pak J Bot 48(4): 1645-1650.

19. Rajput NA, Pathan MA, Lodhi AM, Dou D, Liu T, Arain MS \& Rajer FU (2012). In vitro evaluation of various fungicides against Fusarium solani isolated from Dalbergia sissoo dieback. African $J$ of Microbiol Res 6(27): 5691-5699.

20. Harsh NSK, Chandra S \& Uniyal K (2010). Screening resistance of Dalbergia sissoo clones against Ganoderma lucidum root rot disease in field conditions. For Pathol 41: 221-226

21. Kumar N, \& Khurana SMP (2016). Biomanagement of wilting of a valuable timber and medicinal plant of Shisham (Dalbergia sissoo Roxb.)-A review. Int. J. Curr Microbio Appl Sci 5(1): 32 - 54.

22. Javaid A, Shafique G \& Bashir U (2010). Mycoflora Associated With Stored Seeds Of Different Varieties Of Shisham (DalbergiaSissoo Roxb.) Pak J Phytopathol 22(1): 09-12

23. Poussio GB, Kazmi MR, Akem C \& Fateh FS (2010). First record of Ceratocystis fimbriata associated with shisham (Dalbergia sissoo) decline in Pakistan. Aus Plant Dis Notes 5: 63-65.

24. Ahmad I, Hanan A, Gul S, Ahmad A, Nawaz MF \& Munir U (2015). Frequency of mycoflora associated with Shisham (Dalbergia sissoo) decline in district Faisalabad, Pakistan. Fuuast J Biol 5(2): 225-229.

25. Mukhtar I, Bajwa R \& Nasim G (2014). Trees survival exposed to dieback disease implies evolutionary modulation resistance in shisham (Dalbergia sissoo Roxb.) in various agroecological zones of Punjab (Pakistan). Pak I phytopathol 26 (02): $289-300$.

26. Dasila H, Anjul R, Damini, Anamika R, Manvika S \& Salil T (2018). Interaction between Dalbergia sissoo Roxb. and Pseudomonas koreensis AS15 Strain is Cultivar Specific. Inter J Curr Microbiol App Sci 7(10): 297-306.
27. Pathak VN (1987). Laboratory Mannual of Plant Pathology. 2nd Ed. Oxford IBH Pub. New Delhi (India), pp 23-50.

28. Booth C (1977). The Genus Fusarium CMI, Survey Kew (England).

29. Neergaard P (1979). Seed Pathology. The McMillan Press Ltd. London (England) 1: 240.

30. Khan SM (2002). Tree decline in Pakistan. Integrated plant disease management". In: Proc. of 3rd National Conference of Plant Pathology, NARC, Islamabad 15-16.

31. Khan SM, Shakir AS, Tabssum MA \& Rehman A (2001). Isolation and identification of different fungi from diseased shisham tree. Proc. of 3rd Natl. Conf. of Pl. Pathol. NARCH Islamabad 44-46.

32. Bajwa R, Javaid A \& Shah MBM (2003). Extent of Shisham (Dalbergia sissoo Roxb) Decline in Sialkot, Gujranwala, Lahore and Sargodha Districts. Mycopath 1: $1-5$.

33. Bakhshi BK, \& Singh SL (1959). Root disease of Shisahm (Dalbergia sissoo): Inoculation study on wilt. Indian J. For 85: 415-421.

34. Shakir AS, Khan SM \& Ahmad R (1999). First report on shisham decline in Pakistan. Pak J Phytopathol 11: 106.

35. Khan SH, Idress $M$, Muhammad F, Mahmood A \& Zaidi SH (2004). Incidence of shisham (Dalbergia sissoo Roxb.) decline and in vitro response of isolated fungus spp. to various fungicides. Inter $J$ of Agri and Boil 06: 611-614.

36. Kumar N \& Paul Khurana SMB (2016). Management of Wilting of a Valuable Timber and Medicinal Plant of Shisham (Dalbergia sissoo Roxb.) Inter J Curr Microbiol App Sci 5(1): 32-54.

37. Mukhtar I, Rukhsana B \& Ghazala N (2014). Trees survival exposed to dieback disease implies evolutionary modulation resistance in shisham (Dalbergia sissoo Roxb.) In various agro ecological zones of punjab (pakistan). Pak J Phytopathol 26(02): 289-300. 